EKSAKTA Vol. 12 No. 1, 21-25

\title{
Studi Adsorpsi Larutan Gliserol Menggunakan Karbon Aktif: Efek Konsentrasi, Tegangan Permukaan Dan Temperatur
}

\author{
Yuniawan Hidayat, Atmanto Heru Wibowo, Dwi Ngandayani
}

Jurusan Kimia, FMIPA UNS, Jl. Ir Sutami 36 Surakarta

\begin{abstract}
The effect of adsorbate concentration, surface tension and temperature on glycerol adsorption over activated carbon have been conducted. Activity of adsorbent was increased by soaking activated carbon in $\mathrm{H}_{2} \mathrm{SO}_{4} 10 \%$ solution for 12 hours followed heating at a temperature of $500^{\circ} \mathrm{C}$ under $\mathrm{N}_{2}$ gas flow for 3 hours. Furthermore, the identification and characterization of activated carbon were done by infrared spectroscopy (IR) and gravimetric method acidity test. Conditions of adsorption of glycerol by activated carbon were carried out using batch method with \pm 12 hours of contact time on the variation of adsorbate concentration or the ratio glycerol : water $(\mathrm{v} / \mathrm{v})$ $1: 2,1: 3,1: 4$, and $1: 5$, as well as variations in $30,40,50$, and $60{ }^{\circ} \mathrm{C}$.

The result showed that increased activity of activated carbon increased acidity from $0.5 \mathrm{mmol} / \mathrm{gram}$ to $2.7 \mathrm{mmol} / \mathrm{gram}$. Increasing concentration of glycerol causes the surface tension decreases and $(\partial \gamma / \partial \mathrm{C})$ becomes negative with means that glycerol was adsorbed over the surface. It has been confirmed by the increase of actvated carbon capacity is proportional to the increased concentration of glycerol. Temperature was also playing the role of glycerol adsorption where at $60{ }^{\circ} \mathrm{C}$ maximum adsorption was riched.
\end{abstract}

Keywords: Adsorption, Glycerol, Adsorbate concentration, Temperature, Surface tension, Activated Carbon 